\title{
A Educação Permanente em Saúde durante a pandemia de COVID-19: um aliado na comunicação e conhecimento das equipes
}

\author{
Permanent Health Education during the COVID-19 pandemic: an ally in \\ communication and knowledge of the teams
}

\begin{abstract}
Enderson Rodrigues de Carvalho
Coordenador de Estágios no Centro Universitário Claretiano de Rio Claro, Rio Claro, são Paulo, Brasil. *Autor para correspondência. Email: enderson.car@gmail.com
\end{abstract}

\section{Ponto de vista}

Palavras-chave: educação permanente em saúde, COVID-19, pandemia.

Keywords: permanent health education, COVID-19, pandemic.

A Educação Permanente em Saúde é uma política de extrema importância para o fortalecimento do Sistema Único de Saúde (SUS). Por meio dela, vislumbramos uma série de possibilidades para que, profissionais e equipes, possam ressignificar o ambiente de trabalho por meio de atividades educativas que tragam conteúdos e informações pertinentes a sua função.

Sabemos que os efeitos que a educação tem para transformar a vida das pessoas é notório e comprovado. Trazendo essa possibilidade de mudança para o local de trabalho em que os profissionais de saúde estão inseridos, sua potência se torna ainda maior, visto os ganhos que um trabalhador atualizado e bem informado pode oferecer no cuidado junto as pessoas e na qualidade da assistência em geral.

O momento vivenciado pelos profissionais de saúde que hoje combatem o COVID-19 em nosso País é bem difícil, haja visto a demanda que tem tornado a jornada destes trabalhadores esgotante. Se pensarmos no início da pandemia, quando pouco se sabia ainda sobre a proliferação da doença, formas de contaminação, uso adequado de EPI, entre outras práticas, podemos pensar que o uso da Educação Permanente em Saúde facilitou o engajamento das equipes frente as notícias que chegavam a respeito do COVID-19.

Seja por meio dos encontros semanais ou mensais praticados pelas unidades de saúde em todo o País, essa oportunidade é única para que o trabalhador em saúde dívida conhecimentos, indague suas dúvidas e contribua para o crescimento profissional de todo o grupo. É neste momento, com a presença da equipe multidisciplinar, que todos ganham em uma interação potente e que agrega ao colaborador prática e aprendizados a partir de cenários e rotinas construídas diariamente, sempre de forma diferenciada.

Neste contexto, o uso dessas potências já diagnosticadas pela Educação Permanente em Saúde neste momento de pandemia se faz necessário para que todos os profissionais tenham a sensação de pertencimento junto à toda equipe, além de receber as informações atualizadas referentes a doença. É por meio desse conhecimento esclarecido que ele desenvolve a educação em saúde com a população e promove a prevenção nos territórios de uma forma mais abrangente e certiva.

\section{Minicurrículo}

Enderson Rodrigues de Carvalho. Doutorando do Programa de Clínica Médica da UNICAMP, Mestre em Saúde Coletiva pela UFSCar. 
Como citar: Carvalho, E.R., 2021. A Educação Permanente em Saúde durante a pandemia de COVID-19: um aliado na comunicação e conhecimento das equipes. Pubsaúde, 7, a226. DOI: https://dx.doi.org/10.31533/pubsaude7.a226

Recebido: 12 jul. 2021.

Revisado e aceito: 21 jul. 2021.

Conflito de interesse: os autores declaram, em relação aos produtos e companhias descritos nesse artigo, não ter interesses associativos, comerciais, de propriedade ou financeiros que representem conflito de interesse.

Licenciamento: Este artigo é publicado na modalidade Acesso Aberto sob a licença Creative Commons Atribuição 4.0 (CC-BY 4.0). 